\title{
Perang Dagang Amerika Serikat dan Tiongkok: Bagaimana Dampaknya Bagi Perekonomian Indonesia Tahun 2017 - 2020?
}

\author{
Destri Sambara Sitorus \\ Program Studi Pendidikan Ekonomi \\ Universitas Kristen Satya Wacana \\ Salatiga, Indonesia \\ e-mail: destri.sambara@uksw.edu
}

\author{
Riwayat Artikel \\ Tanggal diajukan: \\ 1 Mei 2021 \\ Tanggal diterima : \\ 18 Mei 2021 \\ Tanggal \\ dipublikasikan: \\ 25 Juni 2021
}

Pengutipan:

Sitorus, D.S.

(2021). Perang

Dagang Amerika

Serikat dan

Tiongkok:

Bagaimana

Dampaknya Bagi

Perekonomian

Indonesia Tahun

2017 - 2020 ?

Jurnal Pendidikan

Ekonomi

Undiksha, 13(1),

187-196

http://dx.doi.org/1

0.23887/jjpe.v13i

$\underline{1.34192}$

\begin{abstract}
Abstrak
Perang dagang yang diawali dengan kebijakan luar negeri Presiden Amerika Serikat yakni Donald Trump yang memberi tarif terhadap barang-barang dari Tiongkok memicu Tiongkok untuk membalas kebijakan tersebut dengan berbagai bentuk proteksi lainnya. Hal ini berdampak bagi pertumbuhan perekonomian global terutama bagi negara-negara yang banyak menjalin kerjasama dengan kedua negara tersebut, termasuk Indonesia. Adapun negara seperti Indonesia yang banyak bergantung dengan kerjasama ekonomi dengan kedua negara terutama dibidang ekspor dan impor sehingga tentu terdampak melalui pertumbuhan ekonominya. Penelitian ini merupakan penelitian kualitatif deskriptif yang bertujuan untuk menjelaskan bagaimana dampak dari perang dagang antara Amerika Serikat dan Tiongkok terhadap perekonomian Indonesia pada tahun 2017 - 2020 menggunakan teori kebijakan luar negeri dan konsep proteksionisme. Hasil kajian menunjukkan bahwa perang dagang antara Amerika Serikat dan Tiongkok memberi dampak yang cukup signifikan bagi perekonomian Indonesia khususnya pada sektor ekspor dan investasi saham.
\end{abstract}

Kata kunci: perang dagang; Amerika Serikat; Tiongkok; Indonesia; perekonomian.

\begin{abstract}
The trade war that began with the foreign policy of the President of the United States, Donald Trump, who imposed tariffs on goods from China, triggered China to retaliate against this policy with various other forms of protection. This has an impact on global economic growth, especially for countries that have a lot of cooperation with the two countries, including Indonesia. As for countries like Indonesia, which depend a lot on economic cooperation with the two countries, especially in the export and import sectors, it is certainly affected by their economic growth. This research is a descriptive qualitative study that aims to explain how the impact of the trade war between the United States and China on the Indonesian economy in 2017 - 2020 using foreign policy theory and the concept of protectionism. The results of the study show that the trade war between the United States and China has had a significant impact on the Indonesian economy, especially in the export sector and stock investment.
\end{abstract}

Keywords: trade war; United States; China, Indonesia; economy.

\section{PENDAHULUAN}

Amerika Serikat merupakan salah satu negara yang bangkit menjadi negara adidaya semenjak perang dingin dengan kemampuan industri dan teknologi yang pesat pada saat itu yang digunakan untuk bersaing dengan negara Uni Soviet yang sekarang ini bernama Rusia. Posisi Amerika Serikat yang terletak diantara dua samudra yaitu Pasifik dan Atlantik membuat perekonomian Amerika Serikat semakin maju secara signifikan. Pada tahun 2017 Amerika Serikat memiliki seorang presiden baru yaitu Donald Trump yang memiliki janji 
kampanye "we make America great again". Dalam hal ini "great again" yang dimaksud dalam kalimat tersebut ditujukan kepada kemakmuran dan kemajuan masyarakat Amerika Serikat yang dinilai menurun saat pemerintahan Presiden Barack Obama (Malloy, 2019). Salah satu faktor dalam kemajuan ini adalah sektor perekonomian Amerika Serikat di dunia internasional yang memegang sektor ekspor hasil industri seperti pesawat terbang, persenjataan dan kendaraan bermotor, dan teknologi. Penggunaan dolar Amerika sebagai alat tukar internasional juga berpengaruh bagi Amerika untuk menguasai perekonomian dunia dengan banyak berinvestasi di negara-negara lain (Deil, 2013). Oleh karena itu, kemajuan dan peningkatan perekonomian menjadi hal utama yang diperhatikan oleh Amerika Serikat dalam kebijakan luar negerinya untuk tetap mempertahankan status sebagai negara adidaya. $\mathrm{Di}$ sisi lain Tiongkok hadir memajukan bidang ekonominya dengan biaya tenaga kerja yang lebih murah sehingga memiliki kemajuan perekonomian yang signifikan.

Tiongkok sendiri merupakan salah satu negara terbesar di Asia dengan jumlah penduduk terbanyak di dunia. Hal ini memberikan keuntungan pada sektor lapangan pekerjaan yang pada saat itu dibutuhkan untuk memajukan ekonomi negara. Tiongkok juga merupakan salah satu negara yang menganut paham komunis dalam sistem pemerintahan sehingga perekonomian mereka merupakan perekonomian tertutup yang berpusat pada negara sebagai pemegang perekonomian tunggal. Pada saat pemerintahan Presiden Deng Xiaoping, Tiongkok melakukan reformasi ekonomi yang menyebabkan kemajuan ekonomi Tiongkok meningkat secara signifikan. Kemajuan ini juga didukung oleh kemampuan Tiongkok yang dapat memproduksi barang dengan harga murah yang diminati oleh negara-negara berkembang hingga saat ini. Akan tetapi beberapa barang tersebut merupakan produk tiruan dari barang asli yang memiliki harga lebih mahal sehingga beberapa negara meragukan kualitas dari barangbarang ekspor hasil produksi Tiongkok (Andina, 2019). Perkembangan ekonomi
Tiongkok yang pesat menyebabkan Amerika Serikat menjadi waspada. Hal ini didasari oleh nilai pertumbuhan ekonomi Amerika yang jauh di bawah Tiongkok dan masuknya produk-produk Tiongkok ke dalam Amerika Serikat.

Dengan meningkatnya ancaman perekonomian yang dapat meningkatkan defisit negara dan ditambah dengan visi Presiden Donald Trump yang akan memakmurkan masyarakat, Amerika menetapkan kebijakan proteksionisme terhadap Tiongkok dengan menetapkan tarif tinggi untuk barang impor. Hal ini bertujuan untuk mengurangi dampak laju perekonomian Tiongkok pada Amerika. Kebijakan proteksi dalam perekonomian sebenarnya sudah dilarang dalam perjanjian FTA (Free Trade Agreement), akan tetapi Amerika mengeluarkan kebijakan ini dengan alasan bahwa Tiongkok meniru dan mencuri Hak Kekayaan Intelektual (HAKI) Amerika dengan meretas beberapa situs dan database teknologi di Amerika yang berisi data dan kemampuan dari produk industri yang dihasilkannya. Dengan alasan tersebut, Amerika bebas menetapkan kebijakan proteksi terhadap Tiongkok. Namun Tiongkok membantah keras tuduhan tersebut dan menetapkan juga kebijakan proteksi kepada Amerika Serikat melalui cara yang sama yaitu menetapkan tarif bea cukai barang impor. Dengan kedua negara saling memberlakukan tarif bea cukai dan menekan pertumbuhan ekonomi pihak luar menjadi awal terjadinya perang dagang antara Amerika Serikat dengan Tiongkok (Sinintya, 2018). Hal ini berpengaruh pada melemahnya pertumbuhan ekonomi dunia termasuk Asia dan khususnya Indonesia yang juga menjalin kerjasama ekonomi dengan kedua negara.

Indonesia

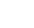
berkembang dalam perekonomian internasionalnya menggunakan kebijakan non blok atau tidak memihak sehingga bekerjasama dengan negara dalam blok apapun termasuk Amerika Serikat dan Tiongkok. Dengan adanya kebijakan proteksi antar kedua negara tersebut, Indonesia mengalami penurunan pada penghasilan produk ekspor yang diakibatkan dari penetapan biaya tarif bea cukai yang tinggi. Hal ini juga berdampak pada 
perekonomian nasional dimana kebutuhan masyarakat semakin meningkat yang memicu untuk melakukan impor barang yang lebih banyak dibandingkan jumlah ekspor sehingga perekonomian Indonesia menurun. Lalu dampak-dampak apa saja yang terjadi dalam perekonomian Indonesia dari tahun awal terjadinya perang dagang tersebut yaitu tahun 2017 hingga tahun 2020 akibat dari hadirnya perang dagang antara Amerika Serikat dengan Tiongkok tersebut?.

\section{Teori Kebijakan Luar Negeri}

Teori kebijakan luar negeri adalah proses dan hasil dari pembuatan keputusan dengan mempertimbangkan referensi dan konsekuensi dari kebijakan tersebut. Seperti dalam kutipannya Palmer \& Morgan (2006) menyatakan, "kami mengidentifikasi bahwa kebijakan luar negeri pertama bermaksud untuk menghasilkan perubahan atau kedua untuk mempertahankan keadaan". Sehingga pada dasarnya kebijakan luar negeri suatu negara adalah untuk mengubah keadaan yang tidak sesuai dengan keinginan negara, serta kebijakan luar negeri akan digunakan untuk mempertahankan kondisi bila ada negara lain yang berusaha mengubah tatanan ekonomi politik internasional. Sehingga kebijakan luar negeri adalah sebuah proses dari sebuah pengambilan keputusan untuk mempertahankan sebuah kepentingan negara.

Adapun proses yang dimaksud dimulai dengan penyelidikan, penentuan prioritas tujuan, penilaian persetujuan dan seterusnya. Bilamana berfokus pada level analisis sistem, kondisi internasional cenderung akan menghasilan tindakantindakan negara untuk mengamankan diri sendiri. Level sistem tidak berfokus pada kebijakan luar negeri satuan negara tertentu, namun di mana kebijakan luar negeri tersebut dibentuk (Hudson, 2005). Kemudian menurut Hudson (2005) terdapat beberapa pemikiran dalam pengambilan kebijakan luar negeri yakni pertama meningkatkan kapabilitas, namun dalam hal ini lebih memilih negosiasi dari pada bertengkar. Kemudian yang kedua bertengkar atau melawan untuk menghindari kegagalan dalam meningkatkan kapabilitas, dan yang ketiga menentang aktor tunggal atau pun koalisisi yang memiliki kecenderungan untuk unggul di dalam sistem (Hudson, 2005).

\section{Konsep Proteksionisme}

Konsep proteksionisme yang merupakan turunan dari teori merkantilisme memberikan pandangannya mengenai bagaimana keuntungan harus diperoleh untuk memajukan roda perekonomian negara sehingga negara harus memunculkan bentuk proteksionisme untuk melindungi para kaum pedagang dari kerugian yang ditimbulkan oleh pasar bebas dan menyetujui bentuk intervensi negara ke dalam pasar. Friedrich List seorang tokoh merkantilis memaknai keinginan pasar bebas dari suatu negara hanya untuk kepentingan para pedagang di negara tersebut. Negara-negara harus membangun kerjasama ekonomi untuk membuka pasar bebas demi keuntungan perdagangan yang akan diperolehnya, karena dasar perjanjian pasar bebas seperti FTA dikendalikan dan disepakati oleh negara maka mustahil pasar bebas hadir tanpa intervensi negara, sehingga walaupun teori merkantilisme sudah tidak lagi relevan di masa modern namun kebijakan proteksionisme secara tersirat tetap dilakukan oleh negara-negara guna melindungi perusahaan-perusahaan dalam negeri (Lim, 2014).

Kemudian proteksionisme sendiri merupakan kebijakan ketat perekonomian dibidang perdagangan internasional dengan langkah suatu negara untuk membatasi perdagangan antar negara yang bertujuan untuk melangsungkan kehidupan perekonomian negara yang melakukannya. Negara yang melakukan proteksionisme secara tersirat akan berusaha untuk menutup pasar dagang antar negara dengan kebijakan pajak, tata cara niaga, serta bea cukai dan hambatan-hambatan perdagangan lainnya sehingga proses perdagangan menjadi terhalang. Kebijakan ini juga bermaksud untuk mengurangi masuknya barang-barang impor ke negara tersebut oleh peraturan pemerintahan yang menerapkan kebijakan ini (Sukirno, 2013).

\section{METODE}

Penelitian ini adalah penelitian kualitatif. Penelitian ini dilakukan dengan cara studi literatur (Moelong, 2017). 
Metodologi deskriptif dapat diartikan sebagai metode menyelidiki suatu fenomena dengan menjelaskan secara subjektif atau objektif dalam penelitian berdasarkan fakta-fakta yang ada. Tujuannya adalah memberikan penjelasan secara sistematis, factual dan akurat berdasarkan fakta, serta kaitannya dengan fenomena yang ada. Adapun objek penelitian dari tulisan ini akan membahas lebih rinci mengenai faktor yang menjadi penyebab dari perang dagang Amerika Serikat dengan Tiongkok dan bagaimana hal tersebut berdampak pada perekonomian Indonesia. Salah satu faktor yang terkena efek dari perang dagang ini adalah perdagangan internasional yang meliputi ekspor dan impor yang merupakan salah satu penghasilan perekonomian internasional Indonesia, karena Indonesia menggunakan ekspor sebagai salah satu penanggulangan turunnya perekonomian Indonesia yang diakibatkan oleh impor barang yang tidak sebanding dengan ekspor ditambah dengan hutang luar negeri yang banyak dan kurangnya infrastruktur yang mendukung yang berpengaruh pada lapangan pekerjaan. Dalam tulisan ini juga akan menjelaskan bagaimana peran para aktor yang berperan dalam memicu perang dagang ini.

\section{HASIL DAN PEMBAHASAN}

Tiongkok merupakan salah satu negara dengan wilayah terbesar ketiga di dunia dan memiliki jumlah penduduk terbanyak yaitu 1,39 miliar jiwa pada perhitungan tahun 2020. Negara ini merupakan salah satu negara di Asia yang menggunakan komunisme sebagai bentuk pemerintahan negaranya sehingga perekonomian Tiongkok menggunakan sistem perekonomian Uni Soviet yaitu sistem perekonomian terencana. Pada tahun 1978, Tiongkok melakukan reformasi perekonomian di bawah pemerintahan Presiden Deng Xiaoping yang mengubah perekonomian tertutup menjadi perekonomian terbuka berorientasi pasar. Salah satu alasan mengapa reformasi ini terjadi adalah kemajuan perekonomian yang secara signifikan pada kawasan Indo-Pasifik dan jenis perekonomian berorientasi pasar yang sukses digunakan oleh negara-negara tetangga Tiongkok pada saat itu. Hal tersebut meningkatkan perekonomian Tiongkok secara signifikan karena di dalam salah satu poin reformasi tertera politik perdagangan terbuka (open-traded policy) yang menggantikan sistem perekonomian tertutup Tiongkok sehingga negara tersebut mendorong adanya perdagangan dan investor internasional seperti ekspor impor dan investasi saham (Brown, 2012).

Sejak menerapkan kebijakan reformasi tersebut, pertumbuhan ekonomi Tiongkok terus meningkat setiap tahunnya hingga pada tahun 2010 pertumbuhan ekonomi Tiongkok dapat menembus angka dua digit yaitu pada 10,6 persen. Pertumbuhan ini membawa dampak positif bagi perekonomian, akan tetapi mereka berpendapat bahwa dalam kebijakan ekonomi tersebut tidak tercantum tujuan yang sebenarnya. Oleh karena itu pada tahun 2012, Presiden Xi Jinping mencetuskan kebijakan perekonomian internasional yang bernama "Chinese dream". "Chinese dream" merupakan sebuah ide kebijakan ekonomi internasional yang berorientasi pada perkembangan dan kemajuan masyarakat dengan dua tujuan utama yaitu menuju masyarakat madani pada tahun 2021 dan modernisasi pada tahun 2049. Tujuan tersebut merupakan dua fundamental dari cita-cita partai komunis China yang dikemukakan oleh presiden sebelumnya yaitu Hu Jintao. Dalam pidato pada pertemuan kongres partai komunis ke18 pada tahun 2012 mengatakan sebagai berikut "kami harus secara kokoh mengacu kepada pemikiran strategis di mana hanya mengutamakan pembangunan" Berdasarkan pernyataan tersebut, Xi Jinping menetapkan kebijakan Chinese dream dalam 3 bidang, yaitu sektor ekonomi, politik, dan militer (Li, 2015). Dua hal kebijakan yang penting dalam Chinese dream tersebut adalah Belt and Road Initiative (BRI) yang bertujuan untuk mengadakan kembali jalur sutera yang dapat meningkatkan perekonomian, dan memiliterisasi pulau-pulau pada kawasan Laut China Selatan (Wang, 2013). Adapun Amerika Serikat merupakan negara adidaya yang memiliki kemampuan industri dan teknologi yang besar untuk 
mempertahankan status sebagai negara adidaya yang menguasai sebagian besar perekonomian dunia.

Salah satu hal yang dilakukan oleh Amerika Serikat adalah menguasai sektor perdagangan pada daerah dan kawasan yang strategis. Kawasan Indo-Pasifik merupakan salah satu wilayah tersebut karena memiliki wilayah yang luas, terdapat banyak negara dan jalur-jalur perdagangan yang strategis di dalamnya. Amerika Serikat mulai memfokuskan perhatiannya pada kawasan Indo-Pasifik setelah Tiongkok menjadi kekuatan ekonomi terbesar pada abad ke-21. Untuk mempertahankan status perekonomian dan pertahanan pada kawasan tersebut dan mengatasi kebijakan "Chinese dream" yang ditetapkan oleh Tiongkok, Amerika Serikat mengeluarkan kebijakan Free and Open Indo-Pacific yang mengacu pada penguasaan sektor perekonomian dan stabilitas keamanan militer pada kawasan Indo-pasifik dan juga kawasan Laut China Selatan (Ali et al., 2018).

Pada tahun 2017, Amerika Serikat di bawah pimpinan Presiden Donald Trump memiliki visi dan misi "we make America great again". "Great again" yang dimaksud oleh slogan tersebut adalah negara Amerika yang makmur, hebat, dan berjaya dalam bidang apapun yang dalam hal ini ditujukan ke dalam bidang perekonomian, industri, teknologi, dan militer. Kebijakan tersebut ditetapkan pada masa pemerintahan Presiden Trump yang bertujuan untuk meningkatkan perekonomian negara, memakmurkan masyarakat Amerika Serikat, dan mempertahankan status sebagai negara adidaya dengan memperluas kerjasama perekonomian internasional dalam bidang perdagangan bebas, ekspor impor, dan investasi saham luar negeri. Sehubungan dengan kebijakan Free and Open Indo-Pacific, Presiden Trump kerap melakukan kunjungan ke negara-negara di Asia untuk mempromosikan kebijakan tersebut dan berusaha mendorong kerja sama dengan berbagai negara guna menjaga jalur laut yang bebas dan terbuka, perdagangan bebas, dan praktik pembiayaan infrastruktur yang transparan.
Presiden Trump juga memberi gagasan terhadap keamanan dan stabilitas kawasan Indo-Pasifik terutama untuk menekan ekspansi militer Tiongkok di Laut China Selatan dan pembuatan senjata Nuklir Korea Utara. Dalam arti lain, kebijakan Free and open Indo-Pacific merupakan kebijakan Amerika Serikat untuk menekan langsung pengaruh dari kebijakan "Chinese dream" Tiongkok pada kawasan Indo-Pasifik dan membangun kerjasama antar negara dalam kawasan tersebut agar dapat menguasai sektor perekonomian internasional dalam kawasan Indo-pasifik. Sebagaimana dibahas dalam teori kebijakan luar negeri (Palmer \& Morgan (2006) bahwa kebijakan luar negeri akan digunakan untuk mempertahankan kondisi bila ada negara lain yang berusaha mengubah tatanan politik internasional. Sehingga kebijakan luar negeri adalah sebuah proses dari sebuah pengambilan keputusan untuk mempertahankan sebuah kepentingan negara.

Pertumbuhan ekonomi Tiongkok pada tahun 2017 sebesar 6,9 persen membuat Amerika Serikat khawatir akan adanya penguasa ekonomi baru dalam kawasan Indo-Pasifik. Hal ini juga didorong oleh pertumbuhan ekonomi Amerika Serikat yang hanya sebesar 2,5 persen pada tahun yang sama. Kemajuan industri Tiongkok dan kebijakan Open-Trade Policy menyebabkan banyaknya barang ekspor dan produk dari Tiongkok yang masuk ke dalam wilayah Amerika Serikat. Hal ini mendorong banyaknya impor barang terhadap Amerika Serikat yang menyebabkan Amerika mengalami defisit. Pada tahun 2017 sendiri, Tiongkok menghasilkan nilai defisit yang signifikan terhadap Amerika Serikat yaitu senilai 375 miliar dollar dari hasil perdagangan antar kedua negara tersebut (Ah, 2017). Jumlah nominal tersebut membuat Tiongkok sebagai negara dengan pemberi defisit terbesar untuk Amerika Serikat. Pada tabel 1 dapat dilihat jumlah defisit Amerika Serikat dari hasil perdagangan dengan Tiongkok (sumber: (Bureau of Economics Analysis).

Tabel 1. Neraca Perdagangan AS Terhadap Tiongkok (Dalam miliar US\$) 


\begin{tabular}{cccc}
\hline Tahun & $\begin{array}{c}\text { Ekspor } \\
\text { (AS - Tiongkok) }\end{array}$ & $\begin{array}{c}\text { Impor } \\
\text { (AS - Tiongkok) }\end{array}$ & Defisit \\
\hline 2011 & 133,88 & 412,41 & 278,54 \\
2012 & 144,89 & 439,83 & 294,94 \\
2013 & 160,37 & 455,52 & 295,15 \\
2014 & 169 & 483,68 & 314,67 \\
2015 & 165,1 & 499,12 & 334,02 \\
2016 & 170,15 & 479,23 & 309,27 \\
2017 & 186,83 & 524,02 & 337,18 \\
2018 & 179,19 & 559,23 & 380,04 \\
2019 & 164,48 & 472,32 & 307,84 \\
2020 & 163,15 & 450,96 & 287,81 \\
\hline
\end{tabular}

\begin{abstract}
Dari tabel 1 diketahui bahwa Amerika selalu mengalami defisit neraca
\end{abstract} perdagangan dengan Tiongkok, walau jumlah defisit terkadang naik dan turun, ditambah dengan banyaknya produk impor Tiongkok yang masuk ke dalam negara membuat Amerika Serikat menetapkan kebijakan proteksionisme terhadap Tiongkok. Hal ini merupakan realisasi dari kampanye "America great again" yang dilaksanakan oleh Presiden Trump untuk mempertahankan dan meningkatkan perekonomian Amerika Serikat dari pengaruh Tiongkok. Kebijakan proteksionisme yang dilakukan oleh Amerika Serikat terdapat pada sektor bea cukai barang impor dimana setiap barang impor Tiongkok yang masuk akan dikenakan biaya tambahan sebesar 25 persen. Hal ini membuat penghasilan Tiongkok dari segi ekspor ke Amerika Serikat menurun. Dari tabel 1 kita dapat melihat sejak ditetapkannya kebijakan tersebut pada tahun 2018, impor dari Tiongkok ke Amerika Serikat mengalami penurunan sampai tahun 2020. Sebagai balasan atas kebijakan tersebut, Tiongkok juga melakukan kebijakan proteksionisme terhadap barang impor Amerika Serikat dengan tambahan biaya yang sama yaitu 25 persen untuk menekan kembali penurunan biaya yang didapat. Kebijakan proteksionisme yang ditetapkan oleh dua negara tersebut menjadi awal dari terjadinya perang dagang antara Amerika Serikat dengan Tiongkok (Steinbock, 2018).

Adapun kebijakan proteksionime merupakan salah satu kebijakan yang dilarang dalam perjanjian Free Trade Agreement (FTA) dimana setiap negara tidak diperkenankan untuk menerapkan kebijakan tersebut terhadap negara lain. Hal ini bertujuan untuk memajukan perekonomian dunia dengan adannya perdagangan internasional antar negara dan kerjasama ekonomi yang dapat membantu perekonomian negara berkembang. Amerika Serikat menerapkan kebijakan tersebut dengan alasan bahwa Tiongkok mencuri HAKI (Hak Kekayaan Intelektual) negaranya. Dalam penjelasannya, Amerika Serikat menilai bahwa perusahaan Tiongkok yang berada di Amerika dan beberapa produk elektronik termasuk program aplikasi merupakan sebuah media yang digunakan oleh Partai Komunis Tiongkok untuk meretas dan mencuri teknologi yang dimiliki oleh Amerika seperti persenjataan militer dan teknologi industri untuk bersaing dengan Amerika Serikat. Hal ini juga didukung dengan bukti dari persenjataan militer Tiongkok seperti pesawat terbang memiliki desain yang mirip dengan persenjataan Amerika Serikat. Berdasarkan dari pernyataan tersebut, Amerika Serikat dapat menetapkan kebijakan 
proteksionisme terhadap Tiongkok secara bebas. Pihak pemerintah Tiongkok membalas tuduhan tersebut sebagai tuduhan yang tidak benar dan menyatakan bahwa Tiongkok akan semakin bebas dan terbuka dalam melakukan perdagangan internasional dengan negara lain untuk mengatasi dampak yang dihasilkan oleh kebijakan proteksionisme ini (Ramadhan, Dkk, 2015).

\section{Dampak Perang Dagang Terhadap Indonesia}

Dalam sektor perekonomian, Indonesia membutuhkan bantuan perekonomian internasional untuk menopang pertumbuhan ekonomi lokal yang lambat akibat kurangnya infrastruktur dan sedikitnya lapangan pekerjaan. Sehingga dalam kerjasama internasional, Indonesia menggunakan sistem kerjasama non-blok, yaitu kerjasama perekonomian bebas dan tidak memihak pada satu sisi. Amerika Serikat dan Tiongkok merupakan mitra dagang Indonesia di bidang ekspor dan impor bahan baku dan non migas. Kebijakan proteksi yang ditetapkan oleh kedua negara membuat perekonomian dunia melambat dan berdampak pada negara di sekitarnya. Kebijakan proteksi Tiongkok menghasilkan sebuah efek domino akan dampak tersebut dimana satu per satu negara disekitarnya ikut terkena mulai dari Kamboja, Vietnam, hingga Indonesia sendiri.

Dampak-dampak yang dialami Indonesia pada tahun awal 2017 masih relatif ringan dimana nilai ekspor bahan baku non migas ke Tiongkok masih bertahan pada nilai 14 persen yakni sebesar 21 miliar dollar Amerika. Hal tersebut menggeser posisi pertama tujuan ekspor non migas Indonesia sebelumnya yaitu Amerika Serikat yang saat itu berada pada nilai 17 miliar dollar Amerika. Pada tahun yang sama, perang dagang tersebut juga mendorong industri lokal dan UMKM lebih bersaing dalam menciptakan produk bernilai ekspor seperti meningkatnya ekspor tekstil Indonesia sebesar 20 hingga 30 persen. Dalam sektor pasar modal seperti IHSG, Indonesia mengalami peningkatan 41,6 poin ke level 6,3 - 6,5 persen. Perekonomian Indonesia juga masih relatif stabil pada angka 5 persen tepatnya pada 5,07 persen pada kuartal IV 2017. Pada gambar 1 dapat dilihat bagaimana grafik pertumbuhan ekonomi Indonesia pada tahun 2017, 2018, dan 2019 masih stabil dari tahun-tahun sebelumnya, namun pada tahun 2020 kuartal I anjlok menjadi 2, 97 persen. Hal ini diakibatkan adanya pandemi COVID-19 yang terjadi di hampir seluruh negara di dunia dan rata-rata perekonomian semua negara juga mengalami penurunan.

Dampak perang dagang yang dialami oleh Indonesia pada tahun 2018 mulai lebih terasa dimana nilai IHSG Indonesia melemah pada level 6.194,50 dan harga ekspor minyak kelapa sawit menjadi 556 dolar Amerika per ton dan 88,3 dolar per ton untuk ekspor batu bara. Walau dampak dari perang dagang dan perlambatan perekonomian dunia mulai merambat ke dalam perekonomian, pasar modal Indonesia mencatat peningkatan secara signifikan pada tahun tersebut dimana BEI mencatat pertumbuhan SID (single id investor) sebanyak 200.935 SID sepanjang tahun 2018 dengan penambahan 1500 investor baru setiap hari. Hal ini didorong juga oleh kebijakan pemerintah untuk meningkatkan produktivitas lokal dan UMKM yang menyebabkan perekonomian Indonesia meningkat menjadi 5,18 persen pada kuartal IV tahun tersebut (BI, 2017). Pada gambar 2 dapat dilihat bagaimana kontribusi UMKM terhadap PDB Indonesia tahun 2010 - 2020. UMKM berkontribusi kurang lebih 57 persen terhadap PBD Indonesia dari tahun 2011 - 2018. Lalu pada tahun 2019 UMKM berkontribusi sebesar 60,3 persen. 


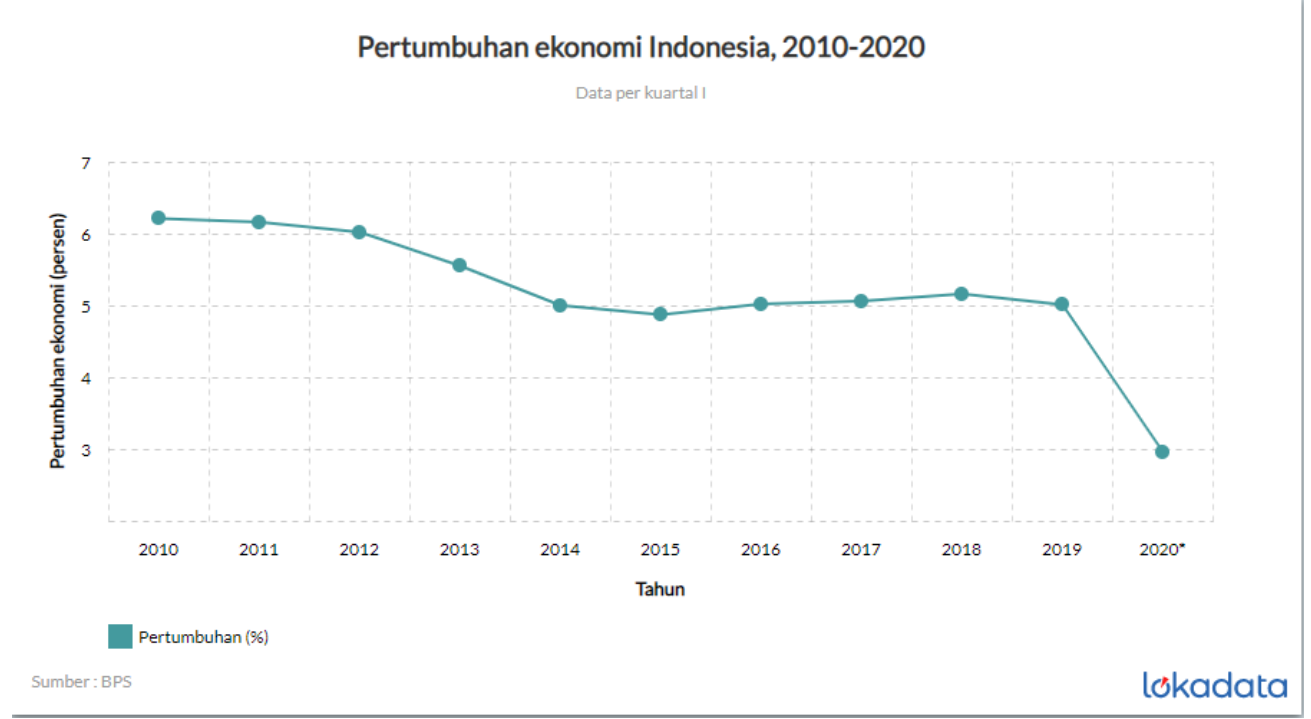

Gambar 2. Kontribusi UMKM terhadap PBD Indonesia Tahun 2010 - 2020
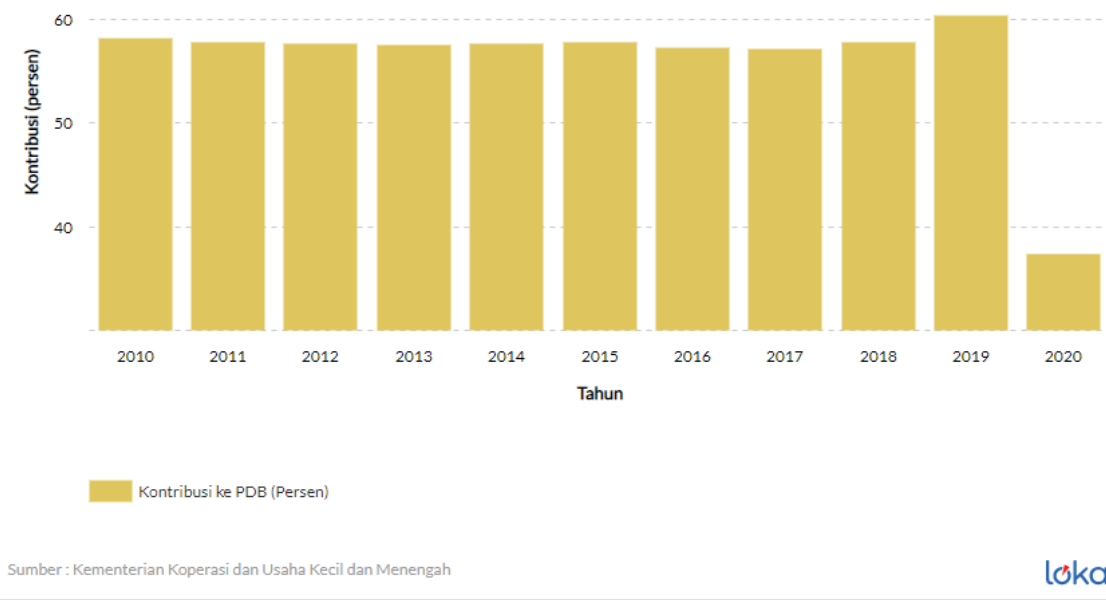

Tahun
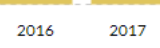

2018

$2019 \quad 2020$

lokadata

Tahun 2019 merupakan puncak dari perang dagang Amerika Serikat dengan Tiongkok dimana dampak yang dihasilkan dari perlambatan ekonomi dunia mulai menyebar ke seluruh negara. Nilai komoditas bahan baku yang menjadi objek ekspor untuk AS dan Tiongkok mengalami penurunan secara signifikan seperti harga minyak kelapa sawit yang pada tahun 2018 bernilai 556 dolar Amerika per ton turun menjadi 500 dolar Amerika per ton dan harga batu bara yang semula bernilai 88,3 dolar Amerika per ton turun menjadi 65 dolar Amerika per ton. Nilai IHSG Indonesia selama 2019 kembali menguat 1,69 persen menjadi level 6,299 persen dengan sektor industri mengalami penurunan terbanyak pada akhir 2019 dengan penurunan sebesar 1,6 persen. Jumlah investor pada pasar modal Indonesia meningkat sebanyak 53 persen menjadi 2,48 juta investor lokal. Dengan adanya dorongan pemerintah terhadap industri lokal dan UMKM juga meningkatnya investor lokal terhadap pasar modal tidak menjamin peningkatan dalam perekonomian karena pada tahun 2019 , nilai perekonomian Indonesia berada pada level 
5,02 persen atau turun sekitar 0,16 persen dibandingkan tahun sebelumnya.

$$
\text { Penyebab turunnya nilai }
$$

perekonomian Indonesia merupakan dampak dari perang dagang itu sendiri yang sudah merambat ke negara lain sehingga melemahkan dan melambatkan perekonomian terhadap 70 negara tujuan ekspor Indonesia yang berpengaruh terhadap harga komoditas dan neraca perdagangan Indonesia. Turunnya IHSG dalam sektor industri juga berdampak pada turunnya perekonomian Indonesia dimana hasil industri lokal pada tahun tersebut tidak optimal karena mahalnya bahan baku impor dan hasil industri dengan harga ekspor yang tidak sebanding dengan kebutuhan bahan impor tersebut. Walau sektor ekspor dan impor mengalami penurunan signifikan, Indonesia tetap dapat menjaga pertumbuhan ekonomi pada kisaran 5 persen dan menjaga inflasi negara tetap dibawah 3,5 persen. Dengan demikian pengaruh kebijakan proteksi yang memicu perang dagang memberi dampak yang cukup signifikan sekalipun Indonesia tetap dapat memajukan perekonomian tanpa terpengaruh dengan perlambatan ekonomi dunia dari tahun ke tahun semenjak kebijakan tersebut ditetapkan.

Pada tahun 2020 perekonomian di berbagai negara mengamali penurunan drastis oleh karena adanya pandemi COVID-19. Namun pada triwulan ke empat keadaan perekonomian sudah mulai membaik, hal ini tercermin pada Indeks PMI global yang menunjukkan peningkatan pada bulan Oktober, serta harga komoditas minyak kelapa sawit, kedelai, serta komoditas hasil tambang di pasar internasional mengalami peningkatan secara baik. Secara keseluruhan pertumbuhan ekonomi tahun 2020 mengalami penurunan sebesar 2,07 persen dari tahun lalu.

\section{SIMPULAN DAN SARAN}

Berdasarkan pemaparan data yang dilakukan pada tahun 2017 pada saat kebijakan luar negeri berupa proteksi yang dilakukan Amerika Serikat terhadap Tiongkok memberi dampak yang cukup signifikan terhadap perekonomian Indonesia khususnya pada sektor ekspor dan investasi saham dimana melambatnya perekonomian negara lain juga menurunkan harga komoditas dari bahan baku Indonesia yang memiliki nilai ekspor tinggi pada tahun-tahun sebelumnya. Kurangnya infrastruktur dan melambatnya perekonomian juga menyebabkan para investor asing kurang meminati saham-saham yang berada pada IHSG Indonesia. Tetapi dari hasil analisis juga ditemukan bahwa kebijakan pemerintah untuk mendorong industri dan UMKM lokal terbukti berhasil menekan dampak yang dihasilkan dari perang dagang terhadap Indonesia dimana nilai perekonomian Indonesia dapat bertahan pada kisaran 5,02- 5,18 persen dibandingkan dengan negara lain yang mengalami penurunan ekonomi dan banyaknya investor lokal pada pasar modal yang meningkat setiap tahunnya. Adapun untuk penelitian selanjutnya dapat memperbaharui pembahasan mengenai bagaimana Indonesia dapat terus mempertahankan kestabilan ekonominya ditengah krisis apapun yang terjadi di dunia dengan menjelaskan faktor-faktor dan bentuk kebijakan yang efektif untuk menjaga kestabilan perekonomian Indonesia.

\section{DAFTAR PUSTAKA}

Ah, O. Y. (2017). China's Economic Ties with Southeast Asia. Sejong: Korea Institute for International Economic Policy.

Ali, T., Ali, W., Ali, M., Raza, B., \& Niazi, A. (2018). China-Pak Economic Corridor (CPEC): Economic TransformationChallenged and Opportunities for the Local Residents. Journal of Politics and International Studies, 4(1), 17-30.

Andina, V. (2019). Implikasi Perang Dagang Amerika-Cina Terhadap Perdagangan Indonesia. Universitas Negeri Jember.

BI, D. K. (2017). Bank Indonesia Mempertahankan Suku Bunga Kebijakan: Ekonomi Global Menguat, Pemulihan Ekonomi Domestik Berlanjut. Bank Indonesia. https://www.bi.go.id/id/publikasi/ruangmedia/newsrelease/Pages/sp_198717.asp

Brown, C. D. (2012). China's Great Leap Forward. Journal Education About Asia. Journal Education About Asia, 17(3), 29-34. 
Bureau of Economics Analysis. (n.d.). https://apps.bea.gov/iTable/iTable.cfm ?ReqID $=62 \&$ step $=1$

Deil, S. A. F. (2013). Rahasia Kenapa Amerika Selalu Merajai Ekonomi Dunia. Liputan https://www.liputan6.com/bisnis/read/6 20148/rahasia-kenapa-amerika-selalumerajai-ekonomi- dunia

Hudson, V. M. (2005). Foreign Policy Analysis: Actor-Specific Theory and the Ground of International Relations. Foreign Policy Analisis. Oxford: International Studies Association, 1, 130.

$\mathrm{Li}, \mathrm{X}$. (2015). Interpreting and Understanding "The Chinese Dream" in a Holistic Nexus. Denmark: Aalborg University.

Lim, T. C. (2014). International Political Economy: An Introduction to Approaches, Regimes, and Issues. Saylor Foundation.

Malloy, A. (2019). CNN Politics. Trump has visited Mar-a-Lago five times more than Trump Tower. CNN. https://edition.cnn.com/2019/11/01/poli tics/donald-trump-mar-a-lago-newyork-trump-tower/index.html

Moelong, L. . (2017). Metode Penelitian Kualitatif. Bandung: PT. Remaja Rosdakarya.

Palmer, G., \& Morgan, T. C. (2006). A Theory of Foreign Policy. New Jersey: Princeton University Press.

Ramadhan, L. A., \& Dkk. (2015). Upaya Amerika Serikat dalam Perlindungan Hak Atas Kekayaan Intelektual Di Tiongkok Melalui USTR. Jurnal Hubungan Internasional, 1(3).

Sinintya, W. (2018). CNBC Indonesia. Serangan Terbaru Trump ke China: Pencurian HAKI AS. CNBC. https://www.cnbcindonesia.com/news/ 20181121144352-4-43068/seranganterbaru-trump-ke-china-pencurianhaki-as

Steinbock, D. (2018). U.S.-China Trade War and Its Global Impacts. World Century Publishing Corporation and Shanghai Institutes for International Studies China Quarterly of International Strategic Studies, 4(4), 515-542.

Sukirno, S. (2013). Makroekonomi Teori Pengantar. Jakarta: Rajawali Pers.
Wang, Z. (2013). The Chinese Dream: Concept and Context. Journal of Chinsese Political Science, 19, 1-13. 